\title{
Characterization of two transketolases encoded on the chromosome and the plasmid pBM19 of the facultative ribulose monophosphate cycle methylotroph Bacillus methanolicus
}

Benno Markert ${ }^{1 \dagger}$, Jessica Stolzenberger ${ }^{1 \dagger}$, Trygve Brautaset $^{2}$ and Volker F Wendisch ${ }^{1 *}$

\begin{abstract}
Background: Transketolase (TKT) is a key enzyme of the pentose phosphate pathway (PPP), the Calvin cycle and the ribulose monophosphate (RuMP) cycle. Bacillus methanolicus is a facultative RuMP pathway methylotroph. B. methanolicus MGA3 harbors two genes putatively coding for TKTs; one located on the chromosome $\left(t t^{\complement}\right)^{\complement}$ and one located on the natural occurring plasmid pBM19 $\left(t k t^{P}\right)$.

Results: Both enzymes were produced in recombinant Escherichia coli, purified and shown to share similar biochemical parameters in vitro. They were found to be active as homotetramers and require thiamine pyrophosphate for catalytic activity. The inactive apoform of the TKTs, yielded by dialysis against buffer containing $10 \mathrm{mM}$ EDTA, could be reconstituted most efficiently with $\mathrm{Mn}^{2+}$ and $\mathrm{Mg}^{2+}$. Both TKTs were thermo stable at physiological temperature (up to $65^{\circ} \mathrm{C}$ ) with the highest activity at neutral pH. Ni ${ }^{2+}$, ATP and ADP significantly inhibited activity of both TKTs. Unlike the recently characterized RuMP pathway enzymes fructose 1,6-bisphosphate aldolase (FBA) and fructose 1,6-bisphosphatase/sedoheptulose 1,7-bisphosphatase (FBPase/SBPase) from B. methanolicus MGA3, both TKTs exhibited similar kinetic parameters although they only share $76 \%$ identical amino acids. The kinetic parameters were determined for the reaction with the substrates xylulose 5-phosphate

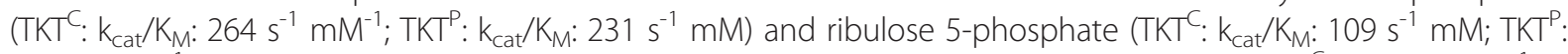
$\mathrm{K}_{\text {cat }} / \mathrm{K}_{\mathrm{M}}: 84 \mathrm{~s}^{-1} \mathrm{mM}$ ) as well as for the reaction with the substrates glyceraldehyde 3-phosphate (TKT $: \mathrm{K}_{\text {cat }} / \mathrm{K}_{M}: 108 \mathrm{~s}^{-1} \mathrm{mM}$; TKT $\left.: k_{\text {cat }} / K_{M}: 71 s^{-1} \mathrm{mM}\right)$ and fructose 6-phosphate $\left(T K T^{C} k_{\text {cat }} / K_{M}: 115 s^{-1} \mathrm{mM} ; T K T^{P}: k_{\text {cat }} / K_{M}: 448 s^{-1} \mathrm{mM}\right.$ ).

Conclusions: Based on the kinetic parameters no major TKT of B. methanolicus could be determined. Increased expression of $t k t^{P}$, but not of $t k^{C}$ during growth with methanol [J Bacteriol 188:3063-3072, 2006] argues for TKT ${ }^{P}$ being the major TKT relevant in the RuMP pathway. Neither TKT exhibited activity as dihydroxyacetone synthase, as found in methylotrophic yeast, or as the evolutionary related 1-deoxyxylulose-5-phosphate synthase. The biological significance of the two TKTs for B. methanolicus methylotrophy is discussed.
\end{abstract}

Keywords: Bacillus methanolicus, Methylotrophy, Ribulose monophosphate (RuMP) pathway, Transketolase (TKT), Thiamine pyrophosphate (THDP) dependent enzyme

\footnotetext{
* Correspondence: volker.wendisch@uni-bielefeld.de

${ }^{\dagger}$ Equal contributors

'Genetics of Prokaryotes, Faculty of Biology \& CeBiTec, Bielefeld University, Universitätsstr. 25, 33615 Bielefeld, Germany

Full list of author information is available at the end of the article
} 


\section{Background}

Transketolase (TKT, EC 2.2.1.1) catalyzes the cleavage of a carbon-carbon bond adjacent to a carbonyl group in ketosugars and transfers a two-carbon ketol group to aldosugars [1,2], a reaction that might already have occurred under prebiotic conditions [3]. TKT requires divalent cations and thiamine diphosphate (ThDP) as a cofactor for its activity [4]. TKT is a key enzyme of the non-oxidative branch of the pentose phosphate pathway (PPP), the Calvin cycle and the ribulose monophosphate (RuMP) cycle. In these metabolic pathways, two ketol group transfers are relevant, the interconversion of xylulose 5-phosphate (X5-P) and ribose 5-phosphate (R5-P) to sedoheptulose 7-phosphate (S7-P) and glyceraldehyde phosphate (GAP) and the interconversion of GAP and fructose 6-phosphate (F6-P) to erythrose 4-phosphate (E4-P) and X5-P [5]. These substrates of TKT are important as precursors e.g. for nucleotide biosynthesis (R5-P), biosynthesis of aromatic amino acids (E4-P) and for cell wall biosynthesis in Gram-negative bacteria (S7-P). They are also intermediates of central pathways of carbon metabolism e.g. glycolysis (F6-P and GAP) and the Calvin and RuMP pathways [6].

TKT occurs in animals, plants, yeasts, archaea and bacteria like Corynebacterium glutamicum [7]. Properties of purified TKT have been reported mostly for eukaryotes like baker's yeast [4], spinach [8], rat liver [9], mouse brain [10], human leukocytes/erythrocytes [11] but also from bacteria such Escherichia coli [12]. TKT is usually a homodimer with two active centers located at the interface between the contacting monomers. Methylotrophic yeasts possess a related enzyme, dihydroxyacetone synthases (DHAS, EC 2.2.1.3), which catalyzes the twocarbon ketol transfer from X5-P to formaldehyde yielding dihydroxyacetone phosphate (DHAP) and GAP. Thus, in these yeasts formaldehyde is assimilated by DHAS and the products DHAP and GAP are further metabolized to regenerate the X5-P and in other reactions of the central carbon metabolism [13]. DHAS has been purified from Candida boidinii [13] and from the carboxydobacterium Acinetobacter sp. [14] and is likely to be present in the actinomycete Amycolatopsis methanolica [15]. Besides DHAS and TKT also DHAS-like proteins have been described, but their function remains unknown [16].

The Gram-positive, thermotolerant and facultative methylotrophic bacterium Bacillus methanolicus that can use the one-carbon $\left(C_{1}\right)$ compound methanol as a source of carbon and energy [17-19] possesses two genes annotated to encode TKT [20]. One of them is encoded on the chromosome $\left(t k t^{C}\right)$, while the other one was found on the natural occurring plasmid pBM19 $\left(t k t^{P}\right)$ $[20,21]$. While the enzymes have not yet been characterized it has been proposed that they play an important role in the PPP and the RuMP pathway [20,22].
The initial reaction of methanol utilization in $B$. methanolicus is the oxidation of methanol to formaldehyde catalyzed by methanol dehydrogenase (MDH) [18]. It is known that $B$. methanolicus possesses three distinct active MDHs [23]. Reduction equivalents are generated by the linear dissimilation pathway of formaldehyde to $\mathrm{CO}_{2}$ and also by the PPP [24,25]. However, no formaldehyde dehydrogenase (FADH) was found in B. methanolicus [21]. Formaldehyde assimilation in B. methanolicus occurs via the RuMP pathway, which is divided in three different parts: fixation, cleavage and regeneration. The key reactions of the RuMP cycle are the aldol condensation of formaldehyde with ribulose 5-phosphate by 3-hexulose-6-phosphate synthase (HPS) and the subsequent isomerization of the product, D-arabino-3-hexulose 6-phosphate, to fructose 6phosphate by 6-phospho-3-hexuloisomerase (PHI) in the fixation part. Fructose 1,6-bisphosphate (FBP) is generated in the subsequent phosphofructokinase reaction (Figure 1). Fructose 1,6-bisphosphate aldolase (FBA, EC 4.1.2.13) cleaves FBP into GAP and DHAP. B. methanolicus has one chromosomal- and one plasmid-encoded FBA $\left(\mathrm{FBA}^{\mathrm{P}}\right.$ and $\mathrm{FBA}^{\mathrm{C}}$, respectively). Both catalyze the reversible cleavage of FBP to the triose phosphates GAP and DHAP [26]. We recently showed that $\mathrm{FBA}^{\mathrm{P}}$ is presumably the major gluconeogenic FBA while $\mathrm{FBA}^{\mathrm{C}}$ is the major glycolytic FBA in this bacterium [26]. The regeneration phase of the RuMP pathway, in which Ru5-P is regenerated, shares enzymes with the PPP and glycolysis [27] (Figure 1). Two different variants of the regeneration part of the RuMP pathway are known, the TA (transaldolase) variant and the SBPase (sedoheptulose 1,7-bisphosphatase) variant. Based on its genome sequence, $B$. methanolicus possesses the whole genetic equipment for both variants of the RuMP pathway [20-22]. In the TA variant, S7-P is directly generated from F6-P and E4-P by a TA activity, while the SBPase variant requires the activity of a sedoheptulose 1,7-bisphosphate aldolase (SBA) to generate sedoheptulose 1,7-bisphosphate (SBP) and an SBPase activity for the further conversion of SBP to S7-P. We recently demonstrated, that both FBAs from $B$. methanolicus are promiscuous enzymes also active as SBA, while only the plasmid encoded $\mathrm{GlpX}^{\mathrm{P}}$ was active as FBPase and SBPase, which indicates that the SBPase variant of the RuMP pathway might operate in this organism [28]. Three enzymes, transketolase (TKT), ribose 5-phosphate isomerase (RPI) and ribulose 5-phosphate 3epimerase (RPE), are shared in both variants. In the RuMP pathway, the predicted function of the TKT(s) is identical to the PPP and Calvin cycle.

It has been shown that the natural plasmid pBM19 carries the key $m d h$ gene and five genes with deduced roles in the RuMP pathway ( $g l p X, f b a, t k t, p f k, r p e)$. The absence of pBM19 results in the loss of the ability to grow on methanol and caused higher methanol tolerance and reduced formaldehyde tolerance levels in $B$. 


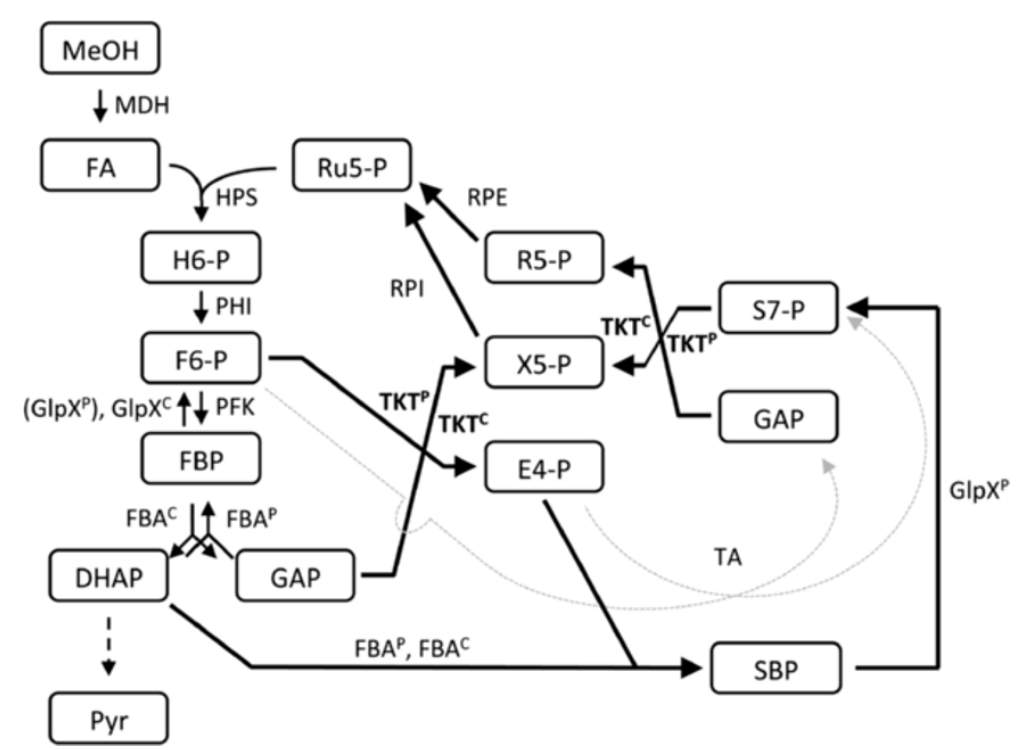

Figure 1 Proposed map of the biochemical reactions of the methanol oxidation and assimilation pathways in B. methanolicus including the TA (dashed arrows) and the SBPase (solid arrows) variants of the RuMP pathway. Enzymes: MDH, methanol dehydrogenase (EC 1.1.1.244); HPS, 3-hexulose-6-phosphate synthase (EC 4.1.2.43); PHI, 6-phospho-3-hexuloisomerase (EC 5.3.1.27); PFK, 6-phosphofructokinase, (EC 2.7.1.11); FBA, fructose-bisphosphate aldolase (EC 4.1.2.13); TKT, transketolase (EC 2.2.1.1); GlpX, fructose-bisphosphatase (EC 3.1.3.1); TA, transaldolase (EC 2.2.1.2); RPE, ribulose- phosphate 3-epimerase (EC 5.1.3.1); RPI, ribose-5-phosphate isomerase (EC 5.3.1.6); Metabolites: H6-P, 3-hexulose 6-phosphate; F6-P, fructose-6-phosphate; FBP, fructose-1,6-bisphosphate; GAP, glyceraldehyde 3-phosphate; DHAP, dihydroxyacetone phosphate; E4-P, erythrose 4-phosphate; SBP, sedoheptulose 1,7-bisphosphate; S7-P, sedoheptulose-7-phosphate; Ri5-P, ribose 5-phosphate; X5P, xylulose 5-phosphate; Ru5P, ribulose 5-phosphate; The reactions are described in detail in the text. Adapted from [28].

methanolicus cells [20]. Transcription levels of $m d h$ and the five plasmid encoded RuMP pathway genes, as well as the chromosomal genes hps and phi, were increased during growth with methanol suggesting their importance for methylotrophy $[21,22]$. Notably, 15 fold higher mRNA $t k t^{P}$ levels were found in methanol- as compared to mannitol-grown cells [21,22]. Methanol consumption by this organism involves the concerted recruitment of both plasmid and chromosomal genes, and this discovery represented the first documentation of plasmid dependent methylotrophy $[20,22,29]$.

The plasmid-encoded enzymes characterized to date differ from their chromosomally encoded counterparts as e.g. the three MDH enzymes exhibit different biochemical and physical properties and their genes are regulated differently [23]. Glp $\mathrm{X}^{\mathrm{C}}$ was shown to be the major FBPase of $B$. methanolicus, while $\mathrm{GlpX}^{\mathrm{P}}$ also carries SBPase activity [28]. Both $\mathrm{FBA}^{\mathrm{C}}$ and $\mathrm{FBA}^{\mathrm{P}}$ are SBAs, but their kinetic parameters allowed to distinguish $\mathrm{FBA}^{\mathrm{C}}$ as major glycolytic $\mathrm{FBA}$ and $\mathrm{FBA}^{\mathrm{P}}$ as major gluconeogenic FBA [26]. The objective of this study was to characterize the role and enzymatic properties of the two TKTs from B. methanolicus to get further insight into the genetic and biochemical aspects of methylotrophy

\section{Results}

Bioinformatic analysis and phylogeny of the $\mathrm{TKT}^{\mathrm{P}}$ and $\mathrm{TKT}^{\mathrm{C}}$ from B. methanolicus

$B$. methanolicus possesses two distinct genes encoding TKT [21], $t k t^{C}$ on the chromosome and the plasmid located $t k t^{P}$. The deduced primary sequences of these proteins show a similarity of $87 \%(578 / 668)$ and an identity of $76 \%(506 / 668)$ to each other. The closest homolog of $\mathrm{TKT}^{\mathrm{C}}$ present in the database is the chromosomally encoded homolog (EIJ77615.1; 97\% identical amino acids) of B. methanolicus strain PB1. Similarly, the closest homolog of plasmid encoded $\mathrm{TKT}^{\mathrm{P}}$ is the TKT (EIJ81398.1) from B. methanolicus PB1 (95\% identical amino acids), which is encoded on plasmid pBM20. BLAST analyses of the amino acid sequences of $\mathrm{TKT}^{\mathrm{C}}$ and $\mathrm{TKT}^{\mathrm{P}}$ as queries suggested their classification as TKT with more than 200 sequences sharing $50 \%$ or more identical amino acids. An amino acid sequence alignment with biochemically characterized and experimentally verified TKTs from E. coli K12, encoded by tktA and tktB [12,30,31], Plasmodium falciparum, encoded by pftk [32], Leishmania mexicana, encoded by $t k t$ [33], Trypanosoma brucei, encoded by tbtkt [34], and Saccharomyces cerevisiae, encoded by sctk [35] revealed the presence of highly conserved amino acid residues 
throughout the sequence with two notable motifs (Figure 2). The first N-terminal located motif is common to all Thiamindiphosphat (ThDP)-dependent enzymes. The sequence begins with the highly conserved residues Gly-Asp-Gly (GDG) followed by 21 less conserved residues [36,37]. The second so-called Tk motif is specific for all TKTs [38].

\section{Overexpression of $t k t^{C}$ and $t k t^{P}$ resulted in increased TKT} activity in $B$. methanolicus

In order to study if the $t k t^{C}$ and $t k t^{P}$ genes encode functionally active TKT enzymes, both genes were overexpressed in B. methanolicus. Plasmids pTH1-tkt ${ }^{C}$ and pTH1-tkt $t^{P}$ were constructed based on pTH1 and with the $t k t$ coding sequences under control of the methanol-inducible $m d h$ promoter [20,39] and used to transform B. methanolicus. To confirm overexpression, TKT activities were determined in crude extracts of the resulting recombinant cells after growth in SOBSuc medium with or without $200 \mathrm{mM}$ methanol. B. methanolicus carrying the empty vector pTH1 showed similar TKT activities regardless of the presence of the inducer $\left(0.073 \pm 0.004 \mathrm{U} \mathrm{mg}^{-1}\right.$ under non-inducing conditions and of $0.075 \pm 0.005 \mathrm{U} \mathrm{mg}^{-1}$ when methanol was present as inducer). When induced by methanol, the overexpression strains carrying either pTH1- $t k t^{C}$ or $\mathrm{pTH} 1-t k t^{P}$ showed significantly increased TKT activities of $0.373 \pm$ 0.052 and $0.351 \pm 0.064 \mathrm{U} \mathrm{mg}^{-1}$, respectively, as compared to non-inducing conditions $(0.082 \pm 0.002$ and $0.083 \pm 0.003 \mathrm{U} \mathrm{mg}^{-1}$, respectively). Thus, overexpression of $t k t^{C}$ and $t k t^{P}$ indeed increased transketolase activities 4-5 fold, confirming that both genes encode functionally active TKTs.

Heterologous expression, purification and biochemical characterization of the $\mathrm{TKT}^{\mathrm{P}}$ and $\mathrm{TKT}^{\mathrm{C}}$

\section{(I) Overexpression, purification and molecular}

\section{mass detection}

The $t k t^{P}$ and $t k t^{C}$ coding regions were PCR-amplified and cloned into pET16b for production of the enzymes with an N-terminal His-tag (Table 1). The resulting plasmids were transformed into E. coli BL21 (DE3) and recombinant protein production was induced by the addition of IPTG to exponentially growing cell cultures. Cells were harvested, crude extracts were prepared and after Ni-NTA chromatography, His-tags were cleaved using factor $\mathrm{Xa}$, and the enzymes were buffered in $50 \mathrm{mM}$ Tris- $\mathrm{HCl}(\mathrm{pH}$ 7.7). Protein purifications from

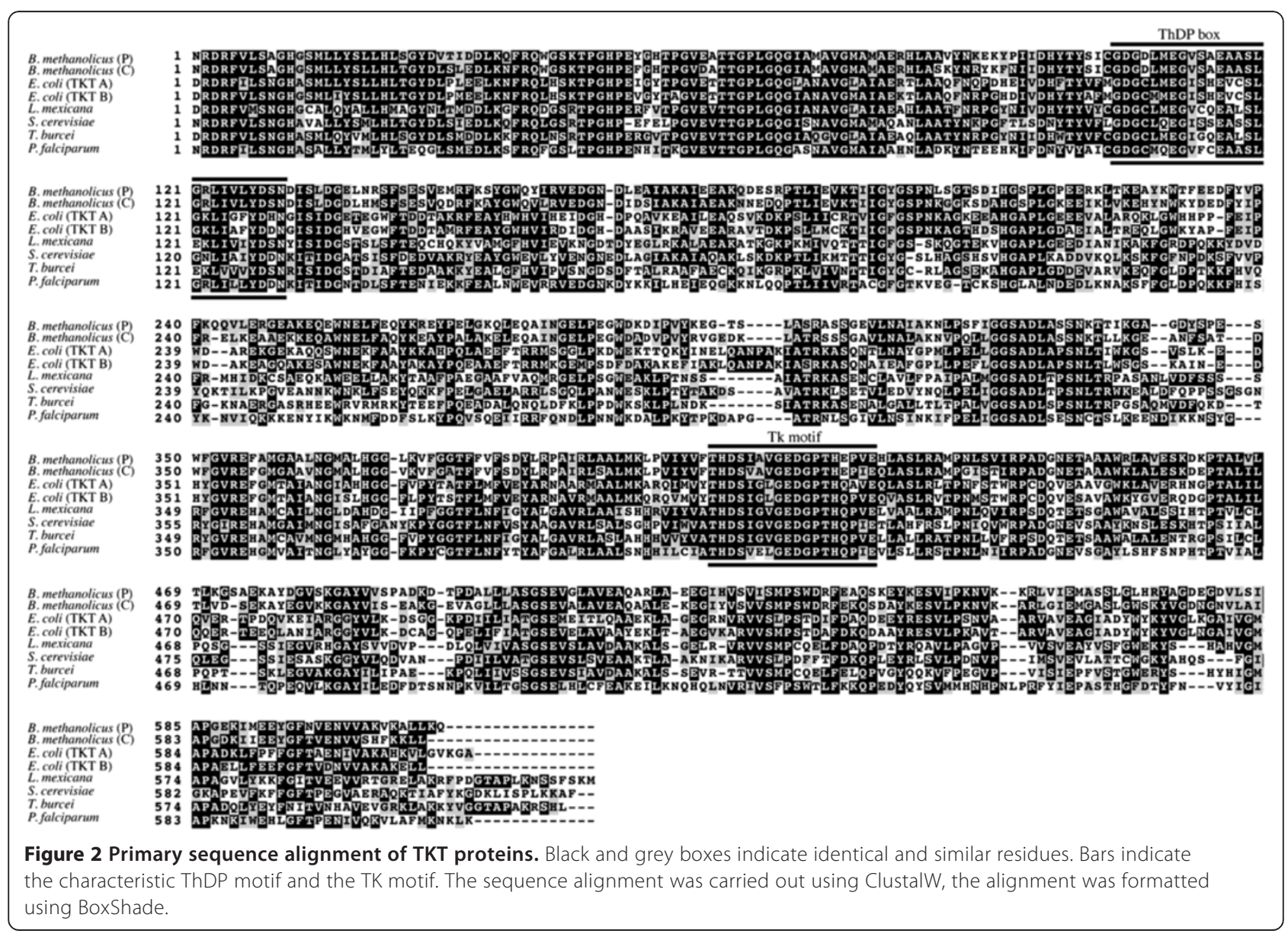


Table 1 List of strains and plasmids used

\begin{tabular}{|c|c|c|}
\hline Strain, plasmid & Function and relevant characteristics & References \\
\hline \multicolumn{3}{|l|}{ B. methanolicus } \\
\hline MGA3 & Wild-type strain & [19] \\
\hline \multicolumn{3}{|l|}{ E. coli } \\
\hline $\mathrm{DH} 5 \mathrm{a}$ & 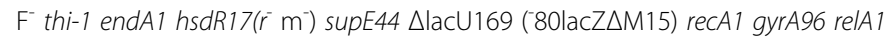 & Bethesda research labs \\
\hline BL21 & ompT hsdSB(rB- mB-) gal dcm (DE3) & Novagen [40] \\
\hline \multicolumn{3}{|l|}{ Plasmids } \\
\hline pEKEX3 & Spe $^{R} ;$ C. glutamicum/E. coli shuttle vector ( $P_{\text {tac }}$ lacla; pBL1, OriV C.g., OriV $\left._{E . c .}\right)$ & [41] \\
\hline pHP13 & B. methanolicus-E. coli shuttle vector; $\mathrm{Clm}^{\mathrm{R}}$ & [42] \\
\hline pHP13mp & pHP13 carrying lys C coding region under control of the mdh promoter & [39] \\
\hline pTH1mp-lysC & Similar as pHP13mp-lysC but with Pcil site upstream mdh promoter removed & [43] \\
\hline pTH1mp & pTH1, but with a mdh promoter upstream to the mcs & This work \\
\hline pTH1-tkt $c^{c}(B m e)$ & Derived from $\mathrm{pTH} 1$, for regulated expression of $t k t^{c}$ of $B$. methanolicus & This work \\
\hline pTH1-tkt (Bme) & Derived from $\mathrm{pTH} 1$, for regulated expression of $t k t^{p}$ of $B$. methanolicus & This work \\
\hline pET16b & Amp ${ }^{R}$; T7lac; vector for his-tagged protein overproduction & (Novagen) \\
\hline pET16b-tkt $(B m e)$ & For production of his-tagged TKT ${ }^{C}$ from B. methanolicus & This work \\
\hline pET16b-tkt (Bme) & For production of his-tagged TKT ${ }^{\mathrm{P}}$ from B. methanolicus & This work \\
\hline pET16b-gapB & Purification of his-tagged E. coli E4PDH from E. coli BL21(DE3) & This work \\
\hline
\end{tabular}

Abbreviations: Spe ${ }^{R}$, spectinomycin resistance; $\mathrm{Clm}^{\mathrm{R}}$, chloramphenicol resistance; $\mathrm{Amp}^{\mathrm{R}}$, ampicillin resistance.

$500 \mathrm{ml}$ of culture broth led to average concentrations of about $1.2 \mathrm{mg} / \mathrm{ml}$ for both enzymes and a total amount of about $3 \mathrm{mg}$ per purification.

Gel filtration of both proteins and TKT activity assays of the eluted fractions showed that both proteins eluted in a single fraction indicating that they are active as homotetramers with molecular weights for the tetramers of $280 \mathrm{kDa}$.

\section{(II) Determining the optimal conditions for TKT activity}

The optimal assay conditions of the TKT enzymes were determined by using a coupled spectrometric assay for measuring the formation of GAP from R5-P and X5-P (as described in Materials and Methods). The activity of the auxiliary enzymes TPI and GPD were first checked under the different conditions and added in excess. Measurements were performed in $50 \mathrm{mM}$ Tris- $\mathrm{HCl}$ buffer at $55^{\circ} \mathrm{C}$ and by using substrate concentrations of $1 \mathrm{mM}$ for both $\mathrm{TKT}^{\mathrm{C}}$ and $\mathrm{TKT}^{\mathrm{P}}$, which is 7 and 5 times greater than the determined $\mathrm{K}_{\mathrm{M}}$ values for $\mathrm{TKT}^{\mathrm{C}}$ and $\mathrm{TKT}^{\mathrm{P}}$, respectively (see below) Activity could be measured for both enzymes within a broad $\mathrm{pH}$ range between 6.5-10 for $\mathrm{TKT}^{\mathrm{C}}$ and 5.5-9 for $\mathrm{TKT}^{\mathrm{P}}$ with a $\mathrm{pH}$ optimum of $\mathrm{pH}$ 7.2-7.4 for both enzymes. All subsequent assays were performed at $\mathrm{pH} 7.5$, the putative physiologically relevant $\mathrm{pH}$.

The influence of the temperature, the $\mathrm{pH}$, the effect of some metal ions and effectors were analyzed using enzyme Assay I (see materials and Methods). TKT activity in different buffers was tested and found to be almost independent of the buffer substance used in concentrations between $20 \mathrm{mM}$ and $200 \mathrm{mM}$. Phosphate buffer, however, showed an inhibitory effect of the TKT activity of approximately $40 \%$.

The highest activity of both TKTs was determined around $62^{\circ} \mathrm{C}$, which corresponds roughly to the upper limit growth temperature of $B$. methanolicus. Temperatures higher than these resulted in strongly decreased TKT activities, which could be, to some extent, explained by the instability of the substrates triose phosphates [44] and/or reflect denaturation of the enzymes.

\section{(III) $T K T^{C}$ displays higher temperature stability than $T K T^{P}$}

The thermal stability of both TKTs was tested by preincubation of the proteins at temperatures ranging from 40 to $80^{\circ} \mathrm{C}$. Samples were taken in different time periods and the activity was measured at $50^{\circ} \mathrm{C}$ under standard conditions. Both TKTs remained stable up to $50^{\circ} \mathrm{C}$ for at least 2 hours. Upon pre-incubation at $60^{\circ} \mathrm{C}$ the catalytic activity was reduced for both enzymes to approximately $60 \%$ within 10 minutes and then remained stable at this level. Incubation at $70^{\circ} \mathrm{C}$ led to a complete loss of activity for $\mathrm{TKT}^{\mathrm{C}}$ after 4 minutes, for $\mathrm{TKT}^{\mathrm{P}}$ after 30 minutes of incubation.

\section{(IV) Formation of the TKT apoform and reconstitution of the holoenzyme revealed a bivalent metal ion dependency for activity}

During optimization of the assay conditions for the TKT activity, a dependence of bivalent cation for both TKTs 
was observed. Therefore, the apo-TKT form was obtained for both B. methanolicus TKTs by removing any bound cofactors via dialysis for 24 hours against Tris$\mathrm{HCl}$ buffer containing $10 \mathrm{mM}$ EDTA. After EDTA was removed by subsequent dialysis, different divalent metal ions, including $\mathrm{Co}^{2+}, \mathrm{Ni}^{2+}, \mathrm{Cu}^{2+}, \mathrm{Mn}^{2+}, \mathrm{Mg}^{2+}$ and $\mathrm{Ca}^{2+}$ were tested as putative cofactors for both TKTs at a final concentration of $1 \mathrm{mM}$ (Figure 3). Reconstitution of the TKT activity was stimulated by $\mathrm{Mn}^{2+}, \mathrm{Mg}^{2+}, \mathrm{Co}^{2+}, \mathrm{Ca}^{2+}$ and $\mathrm{Cu}^{2+}$. The addition of $\mathrm{Ni}^{2+}$ did not restore the TKT activity at all, while slow reconstitution was observed with water, presumably due to contamination of substrates or buffer components with divalent cations.

\section{(V) TKT activities are inhibited by ATP, ADP, EDTA and $\mathrm{Ni}^{2+}$}

To identify inhibitors or activators of $B$. methanolicus TKT activity, potential effectors were tested at concentrations of 1 and $5 \mathrm{mM}$. TKT ${ }^{\mathrm{P}}$ and $\mathrm{TKT}^{\mathrm{C}}$ were both inhibited by ATP (65\% and $75 \%$, respectively) and by ADP (65\% and 95\%, respectively). EDTA in concentration of $10 \mathrm{mM}$ resulted for both TKT in a completely loss of activity. $\mathrm{Ni}^{2+}$ at a concentration of $1 \mathrm{mM}$ also led to a complete loss of activity for both TKT.

\section{$\mathrm{TKT}^{\mathrm{P}}$ and $\mathrm{TKT}^{\mathrm{C}}$ share similar kinetic parameters and substrate spectrum}

The kinetic parameters of $\mathrm{TKT}^{\mathrm{C}}$ and $\mathrm{TKT}^{\mathrm{P}}$ were determined for the conversion of F6-P and GAP to X5-P and E4-P as well as for the formation of S7-P and GAP from $\mathrm{X} 5-\mathrm{P}$ and R5-P in vitro (Table 2). The assays were performed at $60^{\circ} \mathrm{C}$ and $\mathrm{pH} 7.5$ in $50 \mathrm{mM}$ Tris $-\mathrm{HCl}$ with $2 \mathrm{mM} \mathrm{MnCl}_{2}$ and $1 \mu \mathrm{M}$ THDP. Both recombinant TKTs catalyzed the conversion of X5-P and R5-P to GAP and S7-P with comparable kinetic parameters. For X5-P and $\mathrm{TKT}^{\mathrm{C}}$ a $\mathrm{K}_{\mathrm{M}}$ of $150 \mu \mathrm{M} \pm 4 \mu \mathrm{M}$ and a $\mathrm{V}_{\max }$ of $34 \pm 1 \mathrm{U} /$ mg could be determined, whereas $\mathrm{TKT}^{\mathrm{P}}$ displayed a $\mathrm{K}_{\mathrm{M}}$ of $232 \mu \mathrm{M} \pm 2 \mu \mathrm{M}$ and $\mathrm{V}_{\max }$ of $45 \pm 1 \mathrm{U} / \mathrm{mg}$. Similar parameters could be measured for the second substrate R5-P, for which $\mathrm{TKT}^{\mathrm{C}}$ has a $\mathrm{K}_{\mathrm{M}}$ of $118 \mu \mathrm{M} \pm 13 \mu \mathrm{M}$ and a $V_{\max }$ of $11 \pm 1 \mathrm{U} / \mathrm{mg}, \mathrm{TKT}^{\mathrm{P}}$ shows a $\mathrm{K}_{\mathrm{M}}$ of $250 \mu \mathrm{M} \pm 13 \mu \mathrm{M}$ and $\mathrm{V}_{\max }$ of $18 \pm 1 \mathrm{U} / \mathrm{mg}$. The catalytic efficiencies for both TKTs are accordingly quite similar for X5-P (for TKT ${ }^{\mathrm{C}} 264 \mathrm{~s}^{-1} \mathrm{mM}^{-1}$ and for $\mathrm{TKT}^{\mathrm{P}} 231 \mathrm{~s}^{-1} \mathrm{mM}^{-1}$ ) and this also holds for R5-P (for $\mathrm{TKT}^{\mathrm{C}} 109 \mathrm{~s}^{-1} \mathrm{mM}^{-1}$ and for TKT ${ }^{\mathrm{P}} 84 \mathrm{~s}^{-1} \mathrm{mM}^{-1}$ ). Comparable catalytic efficiencies could be calculated for GAP (for TKT $108 \mathrm{~s}^{-1} \mathrm{mM}^{-1}$ and for TKT ${ }^{\mathrm{P}} 71 \mathrm{~s}^{-1} \mathrm{mM}^{-1}$ ) while for F6-P the catalytic efficiency for $\mathrm{TKT}^{\mathrm{P}}$ is about 4-fold higher than that of TKT ${ }^{\mathrm{C}}\left(448 \mathrm{~s}^{-1} \mathrm{mM}^{-1}\right.$ and $115 \mathrm{~s}^{-1} \mathrm{mM}^{-1}$, respectively) Following affinities were observed for GAP $\left(\mathrm{TKT}^{\mathrm{C}} \mathrm{K}_{\mathrm{M}} 0.92 \pm .033 \mathrm{mM}\right.$ and a Vmax $85 \pm 3 \mathrm{U} / \mathrm{mg}$; $\mathrm{TKT}^{\mathrm{P}} \mathrm{K}_{\mathrm{M}} 0.67 \pm .012 \mathrm{mM}$ and $\mathrm{Vmax} 42 \pm 4 \mathrm{U} / \mathrm{mg}$ ) and F6-P $\left(\mathrm{TKT}^{\mathrm{C}} \mathrm{K}_{\mathrm{M}} 0.72 \pm 0.11 \mathrm{mM}\right.$ and a Vmax of $71 \pm 11$ $\mathrm{U} / \mathrm{mg}$; TKT ${ }^{\mathrm{P}}: \mathrm{K}_{\mathrm{M}} 0.25 \mathrm{mM}$ and $\mathrm{Vmax} 96 \pm 5 \mathrm{U} / \mathrm{mg}$ ).

The kinetics of the reverse reactions could not be determined since neither E4-P nor S7-P are currently available commercially. An additional activity as DHAS, as found in methylotrophic yeasts, or as the evolutionary related DXP synthase could not be observed.

\section{Discussion}

The biochemical results provided here show that the plasmid $\left(\mathrm{TKT}^{\mathrm{P}}\right)$ and chromosomally $\left(\mathrm{TKT}^{\mathrm{P}}\right)$ encoded TKTs are similar and based on these data it is not
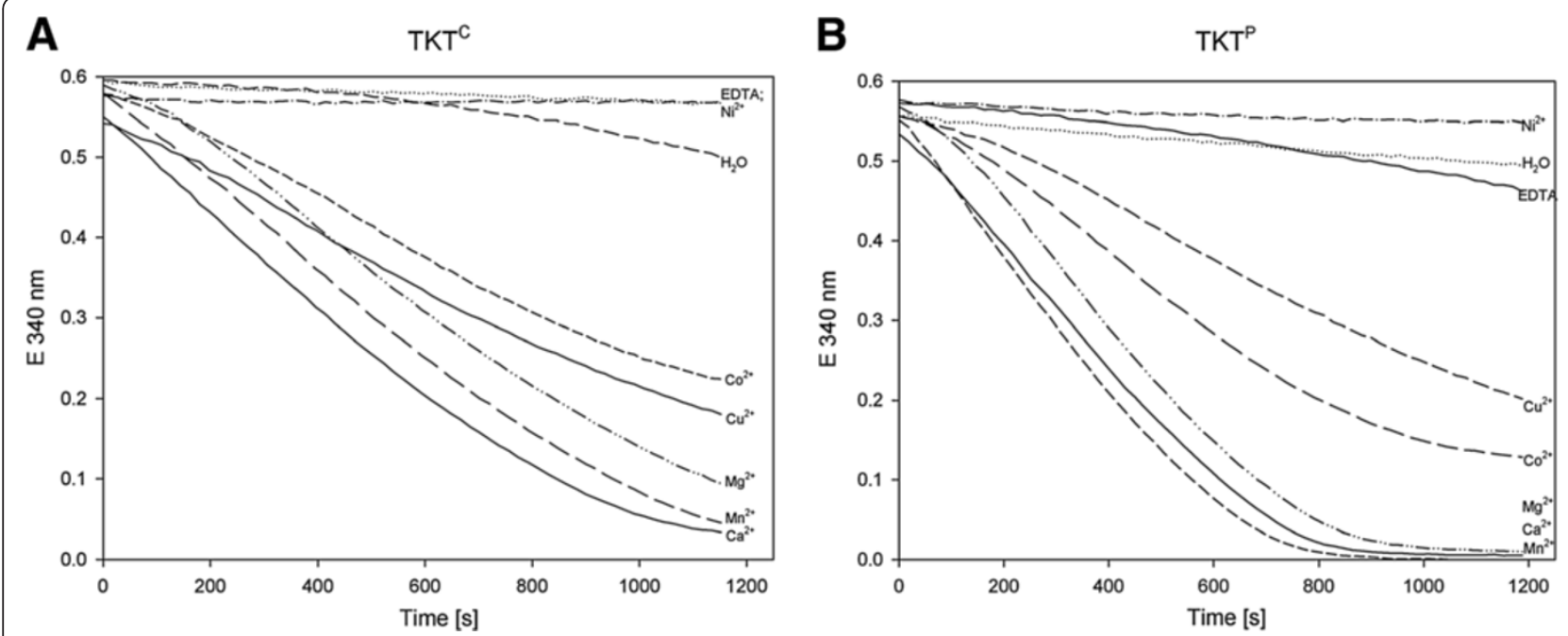

Figure 3 Reconstitution of apoforms of $\operatorname{TKT}^{\mathrm{C}}(\mathrm{A})$ and $\mathrm{TKT}^{\mathrm{P}}(\mathrm{B})$ in the presence of different divalent cations. The reaction was measured according to the enzyme assay I (Methods) with the standard substrates R5-P and X5-P and dialyzed TKT preparations. Each reaction mixture contained $1 \mathrm{mM}$ divalent cations and $150 \mathrm{ng}$ purified TKT enzyme. At $\mathrm{t}=0$, the assay was started by the addition of THDP to a final concentration of $20 \mu \mathrm{M}$. The decrease in absorbance at $340 \mathrm{~nm}$ as a result of NADH oxidation was monitored over time. 
Table 2 Biochemical properties of $\mathrm{TKT}^{\mathrm{P}}$ and $\mathrm{TKT}^{\mathrm{C}}$

\begin{tabular}{|c|c|c|c|}
\hline \multicolumn{2}{|c|}{ Parameter } & $\mathrm{TKT}^{\mathrm{C}}$ & $\mathrm{TKT}^{\mathrm{P}}$ \\
\hline \multirow{2}{*}{\multicolumn{2}{|c|}{ Molecular weight }} & $73 \mathrm{kDa}$ & $73 \mathrm{kDa}$ \\
\hline & & 280 kDa (tetramer) & 280 kDa (tetramer) \\
\hline \multicolumn{2}{|c|}{$\begin{array}{l}\text { Optimal activity } \\
\text { conditions: }\end{array}$} & $\begin{array}{l}50 \mathrm{mM} \text { Tris- }-\mathrm{HCl}, \\
\mathrm{pH} 7.5,2 \mathrm{mM} \mathrm{Mn}{ }^{2+} \\
2 \mu \mathrm{M} \text { THDP, } 55^{\circ} \mathrm{C}\end{array}$ & $\begin{array}{l}50 \mathrm{mM} \text { Tris- } \mathrm{HCl}, \mathrm{pH} 7.7 \\
5 \mathrm{mM} \mathrm{Mn}{ }^{2+}, \\
1 \mu \mathrm{M} \text { THDP, } 55^{\circ} \mathrm{C}\end{array}$ \\
\hline \multicolumn{2}{|c|}{ Optimal pH } & $7.2-7.4$ & $7.2-7.4$ \\
\hline \multicolumn{2}{|c|}{ Optimal temperature } & $62^{\circ} \mathrm{C}$ & $62^{\circ} \mathrm{C}$ \\
\hline \multicolumn{2}{|c|}{ Temperature stability } & $<60^{\circ} \mathrm{C}$ & $<60^{\circ} \mathrm{C}$ \\
\hline \multicolumn{4}{|c|}{ Kinetics } \\
\hline \multirow[t]{4}{*}{$\times 5 P$} & $K_{M}$ & $0.15 \pm 0.01 \mathrm{mM}$ & $0.23 \pm 0.01 \mathrm{mM}$ \\
\hline & $V_{\max }$ & $34 \pm 1 \mathrm{U} / \mathrm{mg}$ & $45 \pm 28 \mathrm{U} / \mathrm{mg}$ \\
\hline & $k_{\text {cat }}$ & $40 s^{-1}$ & $54 \mathrm{~s}^{-1}$ \\
\hline & $\mathrm{k}_{\mathrm{cat}} / \mathrm{K}_{\mathrm{M}}$ & $264 \mathrm{~s}^{-1} \mathrm{mM}^{-1}$ & $231 \mathrm{~s}^{-1} \mathrm{mM}^{-1}$ \\
\hline \multirow[t]{4}{*}{ R5P } & $K_{M}$ & $0.12 \pm 0.01 \mathrm{mM}$ & $0.25 \pm 0.01 \mathrm{mM}$ \\
\hline & $V_{\max }$ & $11 \pm 1 \mathrm{U} / \mathrm{mg}$ & $18 \pm 1 \mathrm{U} / \mathrm{mg}$ \\
\hline & $\mathrm{k}_{\mathrm{cat}}$ & $13 \mathrm{~s}^{-1}$ & $21 \mathrm{~s}^{-1}$ \\
\hline & $\mathrm{k}_{\mathrm{cat}} / \mathrm{K}_{\mathrm{M}}$ & $109 \mathrm{~s}^{-1} \mathrm{mM}^{-1}$ & $84 \mathrm{~s}^{-1} \mathrm{mM}^{-1}$ \\
\hline \multirow[t]{4}{*}{ GAP } & $K_{M}$ & $0.92 \pm 0.03 \mathrm{mM}$ & $0.67 \pm 0.01 \mathrm{mM}$ \\
\hline & $V_{\max }$ & $85 \pm 3 \mathrm{U} / \mathrm{mg}$ & $42 \pm 1 \mathrm{U} / \mathrm{mg}$ \\
\hline & $k_{\text {cat }}$ & $99 \mathrm{~s}^{-1}$ & $48 s^{-1}$ \\
\hline & $\mathrm{k}_{\mathrm{cat}} / \mathrm{K}_{\mathrm{M}}$ & $108 \mathrm{~s}^{-1} \mathrm{mM}^{-1}$ & $71 \mathrm{~s}^{-1} \mathrm{mM}^{-1}$ \\
\hline \multirow[t]{4}{*}{ F6P } & $K_{M}$ & $0.72 \pm 0.11 \mathrm{mM}$ & $0.25 \pm 0.01 \mathrm{mM}$ \\
\hline & $V_{\max }$ & $71 \pm 11 \mathrm{U} / \mathrm{mg}$ & $96 \pm 5 \mathrm{U} / \mathrm{mg}$ \\
\hline & $k_{\text {cat }}$ & $82 s^{-1}$ & $112 s^{-1}$ \\
\hline & $\mathrm{k}_{\mathrm{cat}} / \mathrm{K}_{\mathrm{M}}$ & $115 \mathrm{~s}^{-1} \mathrm{mM}^{-1}$ & $448 s^{-1} \mathrm{mM}^{-1}$ \\
\hline
\end{tabular}

Values for $K_{M}(m M), V_{\max }(U / m g)$, and catalytic efficiency $\left(k_{\text {cat }} / K_{M}=s^{-1} \mathrm{mM}^{-1}\right)$ were determined for two independent protein purifications and mean values and arithmetric deviations from the mean are given.

feasible to predict their individual roles for methylotrophy in B. methanolicus. Both TKTs are active as homotetramers, a characterisitic shared with TKTs from Triticum aestivum and Sus scrova [5], but different from several microbial TKTs such as the enzymes from $E$. coli [12,45], Saccharomyces cerevisiae [46] and Rhodobacer sphaeroides [47]. The requirement of bivalent cations for the activity of TKT from $B$. methanolicus with a preference of $\mathrm{Mn}^{2+} \cdot \mathrm{Mg}^{2+}$, and $\mathrm{Ca}^{2+}$ is a common feature of TKTs, while the efficiency for the cations varies between different TKTs $[12,48]$. It was assumed in the past, that purified mammalian TKTs do not require the addition of cofactors to maintain activity [9]. This led to the wrong conclusion that these enzymes did not require bivalent cations for activity. This was because the complex of TKT with THDP and cation is strong enough to carry the cofactors along the purification steps and though TKT remaining active. The cation can be removed by dialysis against EDTA $[9,49,50]$. Both TKTs showed comparable biochemical properties. This is in contrast to the recently characterized and biochemically diverse MDHs from B. methanolicus, which displayed different biochemical and regulatory properties [23]. Both TKTs were shown to be thermo stable at physiological temperature $\left(50^{\circ} \mathrm{C}\right)$ of $B$. methanolicus. Neutral $\mathrm{pH}(6.5$ to 7.8$)$ was also reported to be optimal for both enzymes of $E$. coli $[13,31]$ and S. cerevisiae [51] and Rhodobacter sphaeroides [47]. Inhibition by ATP and ADP is unusual, however, since the intracellular concentrations of ATP and ADP in B. methanolicus are not known, it is difficult to judge the relevance of this inhibition in vivo.

TKT has been found so far in all organisms that have been investigated [31]. The presence of more than one TKT however, as described here for B. methanolicus is not a common phenomenon. Two TKTs are known in $S$. cerevisiae, encoded by $t k l 1$ and $t k l 2$ [52,53], and E. coli, encoded by $t k t A$ and $t k t B[12,30]$. As in B. methanolicus, the TKTs of $E$. coli and S. cerevisiae exhibit comparable kinetic parameters. However, deletion of $t k l 1$, probably encoding the main TKT in $S$. cerevisiae, impaired growth in synthetic medium without added aromatic amino acids, whereas deletion of $t k l 2$ did not cause such phenotype. In $E$. coli, the $t k t A$ gene product is the major isoenzyme and accounts for about 70 to $90 \%$ of TKT activity in cells and tktA mutants are highly sensitive to the presence of D-ribose, while $t k t B$ deletion mutants are not. $t k t A$ tktB double mutants are viable, but deficient in pentose catabolism and they require the addition of all three aromatic amino acids, aromatic vitamins and pyridoxine (vitamin B6). Transketolase A from Escherichia coli was shown to derepress the multiple antibiotic resistance operon $\operatorname{marR} A B$ by binding to the repressor MarR [54]. It remains to be shown if the TKTs from B. methanolicus show regulatory interactions with transcriptional repressors and if $\mathrm{TKT}^{\mathrm{P}}$ and $\mathrm{TKT}^{\mathrm{C}}$ differ in this respect.

Besides the common sugar phosphates F6-P, R5-P, GAP, X5-P and E4-P, TKTs from spinach leaves and $S$. cerevisiae are able to also utilize DHAP, dihydroxyacetone (DHA) and HP $[50,55,56]$. The reaction of TKTs with formaldehyde (called DHAS) is known in methylotrophic yeasts [57] and was recently also reported for transketolase A of E. coli [31]. However, among all substrates tested, both TKTs form B. methanolicus were only active with X5-P and R5-P as well as F6-P and GAP. Similar substrate specificity was described for mammalian TKTs [58]. Based on the catalytic efficiency $\left(\mathrm{TKT}^{\mathrm{C}} 82 \mathrm{~s}^{-1} \mathrm{mM}^{-1}\right.$ versus $\mathrm{TKT}^{\mathrm{P}} 448 \mathrm{~s}^{-1} \mathrm{mM}^{-1}$ ) TKT ${ }^{\mathrm{P}}$ appears better suited for the interconversion of S7-P and GAP to R5-P and X5-P.

About 15 fold higher mRNA levels of $t k t P$, but not of $t k t C$, were previously observed when comparing growth in minimal medium with methanol and mannitol [21]. This induction was not observed here when assaying 
crude extracts of $B$. methanolicus MGA3(pTH1) which carries endogenous plasmid pBM19 after growth in complex medium SOBSuc induced with $200 \mathrm{mM}$ methanol. Likely, this difference is due to the use of different media, namely complex medium with methanol vs. methanol minimal medium.

\section{Conclusion}

Both, $\mathrm{TKT}^{\mathrm{P}}$ and $\mathrm{TKT}^{\mathrm{C}}$, showed comparable kinetic parameters. The about 15 fold increased mRNA levels of $t k t^{P}$ and of other RuMP pathway genes on the plasmid pBM19, which is essential for methanol utilization $[12,21]$ during growth in methanol minimal medium as compared to growth in mannitol minimal medium [20] argues for $\mathrm{TKT}^{\mathrm{P}}$ being the major $\mathrm{TKT}$ relevant in the RuMP pathway. In line with this argumentation, methanol-inducible $\mathrm{GlpX}^{\mathrm{P}}$ carries SBPase activity, which is relevant in the RuMP pathway [28], while the chromosomally encoded $\mathrm{GlpX}^{\mathrm{C}}$ is the major FBPase in gluconeogenesis and is not methanol-inducible.

\section{Methods}

Microorganisms and cultivation conditions

$B$. methanolicus strains were grown at $50^{\circ} \mathrm{C}$ in the following media. SOBsuc medium is SOB medium (Difco) supplemented with $0.25 \mathrm{M}$ sucrose. Bacterial growth was performed in shake flasks $(500 \mathrm{ml})$ in $100 \mathrm{ml}$ medium at 200 r.p.m. and monitored by measuring the $\mathrm{OD}_{600}$. The inoculation of the precultures for all growth experiments of $B$. methanolicus strains was performed with frozen ampules of B. methanolicus as a starter culture. Ampules of $B$. methanolicus cells were prepared from exponentially growing cultures $\left(\mathrm{OD}_{600} 1.0\right.$ to 1.5$)$ and stored at $-80^{\circ} \mathrm{C}$ in $15 \%(\mathrm{v} / \mathrm{v})$ glycerol [22]. For inoculation, ampules were thawed and $250 \mu \mathrm{l}$ cell suspension was used to inoculate $100 \mathrm{ml}$ medium. The E. coli strain $\mathrm{DH} 5 \alpha$ was used as a standard cloning host [59]. Recombinant cells were grown in lysogeny broth (LB) medium at $37^{\circ} \mathrm{C}$ supplemented with ampicillin $(100 \mu \mathrm{g} / \mathrm{ml})$, kanamycin $(50 \mu \mathrm{g} /$ $\mathrm{ml})$, spectinomycin $(100 \mu \mathrm{g} / \mathrm{ml})$, and $1 \mathrm{mM}$ IPTG when appropriate. Recombinant E. coli procedures were performed as described elsewhere [60]. Recombinant protein production was carried out with E. coli BL21 (DE3) as the host [61]. Bacterial strains and plasmids used in this work are listed in Table 1 and oligonucleotides for PCR and cloning are listed in Table 3.

\section{Homologous overexpression of $t k t^{C}$ and $t k t^{P}$ in $B$. methanolicus}

Overexpression vector pTH1 was used to allow methanol inducible expression of $B$. methanolicus TKT genes. This vector is analogous to the plasmid pHP13, in which the strong $m d h$ promoter was cloned in-frame with the $m d h$ rbs region to allow methanol inducible expression in B. methanolicus [20,39]. The DNA fragments of the $t k t^{C}$ and $t k t^{P}$ coding regions were amplified from DNA of $B$. methanolicus by the primer pair $t k t_{-} \mathrm{P}-\mathrm{Bme}-\mathrm{fw}$ and $t k t \_\mathrm{P}-\mathrm{Bme}-\mathrm{rv}$, and $t k t_{-} \mathrm{C}-\mathrm{Bme}-\mathrm{fw}$ and $t k t_{-} \mathrm{C}-\mathrm{Bme}-\mathrm{fw}$ (Table 3). The resulting PCR products were digested with PciI and ligated to the PciI digested vector pTH1. The resulting vectors were named pTH1-tkt ${ }^{C}$ (Bme) and pTH1-tkt $t^{P}$ (Bme), respectively. Crude cell extracts were prepared based on the protocol described elsewhere [20]. B. methanolicus cells were grown in SOB medium with $0.25 \mathrm{mM}$ sucrose to stationary phase $\left(\mathrm{OD}_{600}, 2.5\right.$ to 3.3). Gene expression was induced by addition of $200 \mathrm{mM}$ methanol at inoculation. $20 \mathrm{ml}$ of the cell culture was harvested by centrifugation $(4000 \times \mathrm{g}, 10 \mathrm{~min}$, $4^{\circ} \mathrm{C}$ ), washed in $50 \mathrm{mM}$ potassium phosphate buffer (pH 7.5) and stored at $-20^{\circ} \mathrm{C}$. The cells were disrupted by sonication described [29]. Cell debris was removed by centrifugation $\left(14,000 \mathrm{x} \mathrm{g}, 1 \mathrm{~h}, 4^{\circ} \mathrm{C}\right)$ and the supernatant was collected as crude extract. TKT activity was measured according to assay II.

\section{Purification molecular mass determination of TKT proteins}

For protein production with E. coli BL21 (DE3) [61], $t \mathrm{kt}^{P}$ and $t k t^{C}$ were amplified by PCR using the primers $t k t_{-} \mathrm{C}-\mathrm{Xho}-\mathrm{fw}$ and $t k t_{-} \mathrm{C}-\mathrm{Xho}-\mathrm{rv}$ and $t k t_{-} \mathrm{P}-\mathrm{Xho}-\mathrm{fw}$ and tkt_P-Xho-rv (Table 3 ). The resulting PCR products were ligated, after restriction with $\mathrm{XhoI}$, into XhoI restricted pET16b (Novagen, Madison, Wisconsin, USA), resulting in pET16b-tkt ${ }^{C}$ and pET16b-tkt $t^{P}$. The pET16b vector allows the production of an $\mathrm{N}$-terminal decahistidine tagged TKT in E. coli BL21 (DE3). Protein production and purification was performed as described previously [62]. Both enzymes were purified to homogenity. After

Table 3 List of oligonucleotides used

\begin{tabular}{ll}
\hline Name & Sequence $\mathbf{( 5}^{\prime}$-3') \\
\hline pET16b_Fw & GCTAACGCAGTCAGGCACCGTGTA \\
pET16b_Rv & GACTCACTATAGGGGAATTGTGAGCG \\
tktC_Fw_Xhol & CCGGCTCGAGTTGTTGATAAAATTGACCAT \\
tktC_Rv_Xhol & CCGGCTCGAGTTATTGTTTAAGTAAAGCT \\
tktP_Fw_Xhol & GCGCCTCGAGGTGCTCCAACAAAAAATAGAT CG \\
tktP_Rv_Xhol & GGCGCTCGAGTTAGAGAAGCTTITTAAAATGAGAAA \\
tkt_C_Seq1 & GCGTCATTGGCAGCGGTATATAAT \\
tkt_C_Seq2 & TCTAGGTCCTGAAGAACGAAAGC \\
tkt_C_Seq3 & GGCTCGGCAGATCTTGCTAGTTC \\
tkt_P_Seq1 & CCCTCATACGCTITTCAGAATC \\
tkt_P_Seq2 & GCTAGAGCATTTAACACTGCACC \\
tkt_P_Seq3 & CGATCTTGAACACTCTCACTAAATG \\
gapb_fw & GCGACTCGAGATGACCGTACGCGTAGCGATAA \\
gapb_rv & GCGTCTCGAGTTACCTGAAAGCAACAGTAGC \\
\hline
\end{tabular}

Restriction sites are highlighted in italics, stop and start codons are underlined. 
purification, the His-tag was cleaved by factor Xa (Novagen, San Diego) according to the manufacturer's recommendations and buffered in $20 \mathrm{mM}$ Tricine, $\mathrm{pH}$ 7.7. The protein purification was analyzed by $12 \%$ SDS-PAGE [63]. Protein concentration was measured according the method of Bradford using the Bio-Rad Protein-Assay with BSA as standard. The tetrameric structures of the TKT proteins were determined by gel filtration as described previously [62] using $1 \mathrm{mg}$ TKT dissolved in $2 \mathrm{ml}$ of $20 \mathrm{mM}$ Tris- $\mathrm{HCl}, \mathrm{pH} 7.5$.

\section{Enzyme assays for the purified TKT proteins}

The TKT activity in the direction of S7P + GAP from $\mathrm{R} 5 \mathrm{P}+\mathrm{Xu} 5 \mathrm{P}$ was done by Assay I, a modified version of a previously described assay [31] using the auxiliary enzymes triose-phosphate isomerase (TPI) and glycerol 3-phosphate dehydrogenase (GPD) from rabbit muscle. The oxidation of NADH was followed setting 1 pmol NADH oxidized equivalent to 1 pmol X5-P consumed. The standard reaction mixture (final volume $1 \mathrm{ml}$ ) contained $50 \mathrm{mM}$ Tris- $\mathrm{HCl}$ buffer ( $\mathrm{pH} 7.5), 0.25 \mathrm{mM}$ $\mathrm{NADH}, 2 \mathrm{mM} \quad \mathrm{Mn}_{2} \mathrm{Cl}, 0.4 \mathrm{U} / \mathrm{ml} \quad \mathrm{TPI}, 0.7 \mathrm{U} / \mathrm{ml}$ glyceraldehyde-3-phosphate dehydrogenase (GAPDH) and purified TKT protein which was preheated for $3 \mathrm{~min}$ at $50^{\circ} \mathrm{C}$. NADH reduction $\left(\varepsilon_{340 \mathrm{~nm}}=6.22 \mathrm{mM}^{-1} \mathrm{~cm}^{-1}\right)$ was followed at $340 \mathrm{~nm}$ on a Shimadzu UV1700 spectrophotometer. The reaction was initiated by the addition of R5-P or X5-P, respectively (final concentration varied between $0.05-10 \mathrm{mM}$ ). The $\mathrm{pH}$-optimum was defined by using the following buffers $(50 \mathrm{mM})$ : acetate (pH 5.0-6.0), phosphate ( $\mathrm{pH}$ 6.0-7.0), Tris- $\mathrm{HCl}$ $(\mathrm{pH}$ 7.0-9.0), and glycine- $\mathrm{NaOH}(\mathrm{pH} 9.0-10.0)$ under standard conditions. The $\mathrm{pH}$ was adjusted at $50^{\circ} \mathrm{C}$.

\section{Formation of the transketolase apoform and reconstitution of the holoenzyme}

Apo-transketolase was obtained by removing the cofactors THDP and divalent cation through dialysis for 24 hours against Tris-HCl buffer $\mathrm{pH} 7.5$ containing $10 \mathrm{mM}$ EDTA. After removing EDTA by dialysis, different divalent cations were tested as possible cofactors in the transketolase reaction using Assay I and $1.25 \mathrm{mM}$ X5-P and R5-P, respectively.

The effect of metal ions and EDTA, ATP or ADP on TKT activity was measured under standard conditions (Assay I) in the presence of $\mathrm{Ca}^{2+}, \mathrm{Co}^{2+}, \mathrm{Cu}^{2+}, \mathrm{Mg}^{2}, \mathrm{Mn}^{2+}$ and $\mathrm{Ni}^{2+}$ at $1 \mathrm{mM}$ final concentration in the reaction mixture. The remaining percentage activities were determined by comparison with no metal ion added. To investigate the effect of EDTA, EDTA salt solution was incubated with TKT for 4 minutes. The measurement was done according to standard assay conditions with $1 \mathrm{mM}$ EDTA final concentration in $1 \mathrm{ml}$ reaction mixture. To study the thermal stability of the TKT proteins, the assay mixture described above was prepared in $1.5 \mathrm{ml}$ reaction tubes and incubated for up to $2 \mathrm{~h}$ at $30-80^{\circ} \mathrm{C}$. Samples were taken periodically and the residual enzyme activity was measured under standard conditions (Assay I) in a separate reaction mixture.

The TKT activity in the direction of E4-P and X5-P from F6-P + GAP was done by Assay II, a modified version of a previously described assay [31] using the auxiliary enzymes Erythrose-4-phosphate dehydrogenase (E4PDH) from E. coli to detect E4-P from the conversion of F6-P and GAP. The oxidation of NADH was followed setting $1 \mathrm{mmol} \mathrm{NADH}$ oxidized equivalent to $1 \mathrm{mmol} \mathrm{X} 5$-P consumed. The standard reaction mixture (final volume $1 \mathrm{ml}$ ) contained $50 \mathrm{mM}$ Tris- $\mathrm{HCl}$ buffer (pH 7.5), $0.25 \mathrm{mM} \mathrm{NAD}{ }^{+}, 2 \mathrm{mM} \mathrm{Mn} \mathrm{ml}_{2} \mathrm{Cl} \mathrm{mM}$ dithiothreitol (DTT) $2 \mathrm{U} / \mathrm{ml}$ E4PDH and purified TKT protein which was preheated for $3 \mathrm{~min}$ at $55^{\circ} \mathrm{C}$. $\mathrm{NAD}^{+}$oxidation $\left(\varepsilon_{340 \mathrm{~nm}}=6.22 \mathrm{mM}^{-1} \mathrm{~cm}^{-1}\right)$ was followed at $340 \mathrm{~nm}$ on a Shimadzu UV1700 spectrophotometer. The reaction was initiated by the addition of GAP or R5-P respectively (final concentration varied between $0.05-10 \mathrm{mM}$ ).

Hydroxypyruvate (HP) activity (Assay III) was measured by recording the oxidation rate of the $\alpha$-carbanion intermediate in the presence of ferricyanide according to the method of Joshi and coworkers (2008) [32]. The reaction mixture in $1.0 \mathrm{ml}$ contained $50 \mathrm{mM}$ glycyl-glycine buffer ( $\mathrm{pH}$ 7.6), $2 \mathrm{mM}$ manganese chloride, $0.2 \mathrm{mM}$ THDP, $0.5 \mathrm{mM}$ potassium ferricyanide, $3 \mathrm{mM}$ F6-P/HP and $0.24 \mathrm{mg}$ enzyme protein. The reaction was initiated by the addition of enzyme and the reduction of ferricyanide was monitored at $420 \mathrm{~nm}$ using UV-1700 PC spectrophotometer (Shimadzu, Japan).

DHAS activity was assayed (Assay IV), depending on the purpose of the experiment, by one of three methods described previously [23,27], with several modifications. For routine assay and to test the effects of glycoaldehyde acceptors on DHAS activity, the activity was measured by a modification of the method of Kato et al. [27] (method A). The reaction mixture $(1 \mathrm{ml})$ contained $50 \mathrm{mmol}$ of standardbuffer ( $\mathrm{pH} \mathrm{7.0),} 0.5 \mathrm{mmol}$ of X5-P, $5 \mathrm{mmol}$ of $\mathrm{MgCl}_{2}, 0.5 \mathrm{mmol}$ of THDP, $0.16 \mathrm{mmol}$ of NADH, 62.6 U TPI (from baker's yeast; Sigma Chemical Co.), $0.26 \mathrm{U}$ of a GPD (from rabbit muscle; Sigma), and cell extracts.

To test the effect of glyceraldehyde donors on DHAS activity, the activity was assayed by a method based on the system described by Waits and Quayle [23] (method $B)$. The reaction mixture of method B was the same as that for method A except that the mixture $(1 \mathrm{ml})$ contained $1 \mathrm{mmol}$ ATP and $0.23 \mathrm{U}$ of glycerokinase (from Candida mycoderma; Sigma) instead of TPI. The mixtures for methods A and B were incubated for $90 \mathrm{~s}$ to determine endogenous activity. The reaction was started by the addition of $1 \mathrm{mmol}$ of formaldehyde, and the 
reduction in absorbance at $340 \mathrm{~nm}\left(\varepsilon_{340 \mathrm{~nm}}=6.22 \mathrm{mM}^{-1} \mathrm{~cm}^{-1}\right)$ was measured between 75 and $105 \mathrm{~s}$ after addition of formaldehyde. One unit of enzyme activity was defined as the amount of enzyme required oxidizing $1 \mathrm{mmol}$ of NADH per min.

\section{Computational analysis}

Sequence comparisons were carried out with protein sequences obtained from the NCBI database (http://www. ncbi.nlm.nih.gov), the sequence alignment of the $B$. methanolicus MGA3 TKT proteins and other TKT was done using CLUSTALW [64] and formatted with Box Shade.

\section{Abbreviations \\ ADP: Adenosine diphosphate; ATP: Adenosine triphosphate; Bme: $B$. methanolicus; C: Chromosomal; DHA: Dihydroxyacetone; DHAP: Dihydroxyacetone phosphate; DHAS: Dihydroxyacetone synthase; DTT: Dithiothreitol; DXP: 1-deoxy-D-xylulose 5-phosphate Synthase; E4-P: Erythrose 4-phosphate; Eco: E. coli; EDTA: Ethylenediaminetetraacetic acid; F6-P: Fructose 6-phosphate; FBA: Fructose 1,6-bisphosphate aldolase; FADH: Formaldehyde dehydrogenase; FBP: Fructose 1,6-bisphosphate; FBPase: Fructose 1,6- bisphosphatase; GAP: Glyceraldehyde phosphate; GlpX: Fructose bisphosphatase; HP: Hydroxypyruvat; HPS: 3-hexulose-6-phosphate synthase; MDH: Methanol dehydrogenase; P: Plasmid; PPP: Pentose phosphate pathway; PHI: 6-phospho-3- hexuloisomerase; R5-P: Ribose 5-phosphate; RPE: Ribulose 5-phosphate 3- epimerase; RPI: Ribose 5-phosphate isomerase; Ru5-P: Ribulose 5-phosphate; RuMP: Ribulose monophosphate; S7-P: Sedoheptulose 7-phosphate; SBA: Sedoheptulose 1,7-bisphosphate aldolase; SBPase: Sedoheptulose 1,7-bisphosphatase; TA: Transaldolase; ThDP: Thiamine diphosphate; TKT: Transketolase; X5-P: Xylulose 5-phosphate.}

\section{Authors' contribution}

VFW, BM, JS and TB designed the experiments. BM and JS conducted the experiments, analysed the results, and wrote the manuscript. VFW and TB reviewed and revised the manuscript. All authors read and approved the final manuscript.

\section{Author details}

${ }^{1}$ Genetics of Prokaryotes, Faculty of Biology \& CeBiTec, Bielefeld University, Universitätsstr. 25, 33615 Bielefeld, Germany. ${ }^{2}$ Department of Molecular Biology, SINTEF Materials and Chemistry, Sem Selands vei 2A, 7465, Trondheim, Norway.

Received: 13 October 2013 Accepted: 7 January 2014 Published: 9 January 2014

\section{References}

1. Schenk G, Duggleby RG, Nixon PF: Properties and functions of the thiamin diphosphate dependent enzyme transketolase. Int J Biochem Cell Biol 1998, 30:1297-1318.

2. Zhao J, Zhong CJ: A review on research progress of transketolase. Neurosci Bull 2009, 25:94-99.

3. Breslow R, Appayee C: Transketolase reaction under credible prebiotic conditions. Proc Natl Acad Sci U S A 2013, 110:4184-4187.

4. Datta AG, Racker E: Mechanism of action of transketolase I Properties of the crystalline yeast enzyme. J Biol Chem 1961, 236:617-623.

5. Kochetov GA: Transketolase from yeast, rat liver, and pig liver. Methods Enzymol 1982, 90(Kochetov GA):E:209-223.

6. Kamada N, Yasuhara A, Takano Y, Nakano T, Ikeda M: Effect of transketolase modifications on carbon flow to the purine-nucleotide pathway in Corynebacterium ammoniagenes. Appl Microbiol Biotechnol 2001, 56:710-717.

7. Abe S, Takayarna K, Kinoshita S: Taxonomical studies on glutamic acid producing bacteria. J Gen Appl Microbiol 1967, 13:279-301.
8. Villafranca JJ, Axelrod B: Heptulose synthesis from nonphosphorylated aldoses and ketoses by spinach transketolase. J Biol Chem 1971, 246:3126-3131.

9. Masri SW, Ali M, Gubler CJ: Isolation of transketolase from rabbit liver and comparison of some of its kinetic properties with transketolase from other sources Comparative biochemistry and physiology. Comp Biochem Physiol B 1988, 90:167-172.

10. Blass JP, Piacentini S, Boldizsar E, Baker A: Kinetic studies of mouse brain transketolase. J Neurochem 1982, 39:729-733.

11. Mocali A, Paoletti F: Transketolase from human leukocytes Isolation, properties and induction of polyclonal antibodies. Eur J Biochem 1989, 180:213-219.

12. Sprenger GA, Schorken U, Sprenger G, Sahm H: Transketolase A of Escherichia coli K12 Purification and properties of the enzyme from recombinant strains. Eur J Biochem 1995, 230:525-532.

13. Kato N, Higuchi T, Sakazawa C, Nishizawa T, Tani Y, Yamada H: Purification and properties of a transketolase responsible for formaldehyde fixation in a methanol-utilizing yeast, candida boidinii (Kloeckera sp) No 2201. Biochim Biophys Acta 1982, 715:143-150

14. Ro YT, Eom CY, Song T, Cho JW, Kim YM: Dihydroxyacetone synthase from a methanol-utilizing carboxydobacterium, Acinetobacter sp strain JC1 DSM 3803. J Bacteriol 1997, 179:6041-6047.

15. Alves AM, Euverink GJ, Hektor HJ, Hessels Gl, van der Vlag J, Vrijbloed JW, Hondmann D, Visser J, Dijkhuizen L: Enzymes of glucose and methanol metabolism in the actinomycete Amycolatopsis methanolica. J Bacteriol 1994, 176:6827-6835.

16. Nakagawa T, Fujimura S, Ito T, Matsufuji Y, Ozawa S, Miyaji T, Nakagawa J, Tomizuka N, Yurimoto H, Sakai Y, Hayakawa T: Molecular characterization of two genes with high similarity to the dihydroxyacetone synthase gene in the methylotrophic yeast Pichia methanolica. Biosci Biotechnol Biochem 2010, 74:1491-1493.

17. Arfman N, Dijkhuizen L, Kirchhof G, Ludwig W, Schleifer KH, Bulygina ES, Chumakov KM, Govorukhina NI, Trotsenko YA, White D, et al: Bacillus methanolicus sp nov, a new species of thermotolerant, methanolutilizing, endospore-forming bacteria. Int J Syst Evol Microbiol 1992, 42:439-445.

18. Arfman N, Hektor HJ, Bystrykh LV, Govorukhina NI, Dijkhuizen L, Frank J: Properties of an $\mathrm{NAD}(\mathrm{H})$-containing methanol dehydrogenase and its activator protein from Bacillus methanolicus. Eur J Biochem 1997, 244:426-433.

19. Schendel FJ, Bremmon CE, Flickinger MC, Guettler M, Hanson RS: L-lysine production at $50^{\circ} \mathrm{C}$ by mutants of a newly isolated and characterized methylotrophic Bacillus sp. Appl Environ Microbiol 1990, 56:963-970.

20. Brautaset T, Jakobsen OM, Flickinger MC, Valla S, Ellingsen TE: Plasmiddependent methylotrophy in thermotolerant Bacillus methanolicus. J Bacteriol 2004, 186:1229-1238.

21. Heggeset TM, Krog A, Balzer S, Wentzel A, Ellingsen TE, Brautaset T: Genome sequence of thermotolerant Bacillus methanolicus: features and regulation related to methylotrophy and production of L-lysine and L-glutamate from methanol. Appl Environ Microbiol 2012, 78:5170-5181.

22. Jakobsen OM, Benichou A, Flickinger MC, Valla S, Ellingsen TE, Brautaset T: Upregulated transcription of plasmid and chromosomal ribulose monophosphate pathway genes is critical for methanol assimilation rate and methanol tolerance in the methylotrophic bacterium Bacillus methanolicus. J Bacteriol T E 2006, 188:3063-3072.

23. Krog A, Heggeset TM, Muller JE, Kupper CE, Schneider O, Vorholt JA, Ellingsen TE, Brautaset T: Methylotrophic Bacillus methanolicus encodes two chromosomal and one plasmid born $\mathrm{NAD}(+)$ dependent methanol dehydrogenase paralogs with different catalytic and biochemical properties. PLoS One 2013, 8:e59188.

24. Anthony C: Bacterial oxidation of methane and methanol. Adv Microb Physiol 1986, 27:113-210

25. de Vries GE, Arfman N, Terpstra P, Dijkhuizen L: Cloning, expression, and sequence analysis of the Bacillus methanolicus C1 methanol dehydrogenase gene. J Bacteriol 1992, 174:5346-5353.

26. Stolzenberger J, Lindner SN, Wendisch VF: The methylotrophic Bacillus methanolicus MGA3 possesses two distinct fructose 1,6-bisphosphate aldolases. Microbiol 2013, 159:1770-1781.

27. Brautaset $T$, Jakobsen OM, Josefsen KD, Flickinger MC, Ellingsen TE: Bacillus methanolicus: a candidate for industrial production of amino acids from methanol at $50^{\circ} \mathrm{C}$. Appl Microbiol Biotechnol 2007, 74:22-34. 
28. Stolzenberger J, Lindner SN, Persicke M, Brautaset T, Wendisch VF: Characterization of fructose 1,6-bisphosphatase and sedoheptulose 1,7-bisphosphatase from the facultative ribulose monophosphate cycle methylotroph Bacillus methanolicus. J Bacteriol 2013, 195:5112-5122.

29. Brautaset T, Williams MD, Dillingham RD, Kaufmann C, Bennaars A, Crabbe E, Flickinger MC: Role of the Bacillus methanolicus citrate synthase II gene, cit $Y$, in regulating the secretion of glutamate in L-lysine-secreting mutants. Appl Environ Microbiol 2003, 69:3986-3995.

30. lida A, Teshiba S, Mizobuchi K: Identification and characterization of the tktB gene encoding a second transketolase in Escherichia coli K-12. J Bacteriol 1993, 175:5375-5383.

31. Zhao G, Winkler ME: An Escherichia coli K-12 tktA tktB mutant deficient in transketolase activity requires pyridoxine (vitamin $B 6$ ) as well as the aromatic amino acids and vitamins for growth. J Bacteriol 1994, 176:6134-6138.

32. Joshi S, Singh AR, Kumar A, Misra PC, Siddiqi MI, Saxena JK: Molecular cloning and characterization of Plasmodium falciparum transketolase. Mol Biochem Parasitol 2008, 160:32-41

33. Veitch NJ, Maugeri DA, Cazzulo JJ, Lindqvist Y, Barrett MP: Transketolase from Leishmania mexicana has a dual subcellular localization. Biochem J 2004, 382:759-767.

34. Stoffel SA, Alibu VP, Hubert J, Ebikeme C, Portais JC, Bringaud F, Schweingruber ME, Barrett MP: Transketolase in Trypanosoma brucei. Mol Biochem Parasitol 2011, 179:1-7.

35. Golbik R, Meshalkina LE, Sandalova T, Tittmann K, Fiedler E, Neef H, Konig S, Kluger R, Kochetov GA, Schneider G, Hubner G: Effect of coenzyme modification on the structural and catalytic properties of wild-type transketolase and of the variant E418A from Saccharomyces cerevisiae. FEBS J 2005, 272:1326-1342.

36. Hawkins CF, Borges A, Perham RN: A common structural motif in thiamin pyrophosphate-binding enzymes. FEBS Lett 1989, 255:77-82

37. Meshalkina L, Nilsson U, Wikner C, Kostikowa T, Schneider G: Examination of the thiamin diphosphate binding site in yeast transketolase by site-directed mutagenesis. Eur J Biochem 1997, 244:646-652.

38. Abedinia M, Layfield R, Jones SM, Nixon PF, Mattick JS: Nucleotide and predicted amino acid sequence of a cDNA clone encoding part of human transketolase. Biochem Biophys Res Commun 1992, 183:1159-1166.

39. Jakobsen OM, Brautaset T, Degnes KF, Heggeset TM, Balzer S, Flickinger MC, Valla S, Ellingsen TE: Overexpression of wild-type aspartokinase increases L-lysine production in the thermotolerant methylotrophic bacterium Bacillus methanolicus. Appl Environ Microbiol 2009, 75:652-661.

40. Kelley-Loughnane N, Biolsi SA, Gibson KM, Lu G, Hehir MJ, Phelan P, Kantrowitz ER: Purification, kinetic studies, and homology model of Escherichia coli fructose-1,6-bisphosphatase. Biochim Biophys Acta 2002, 1594:6-16.

41. Stansen C, Uy D, Delaunay S, Eggeling L, Goergen JL, Wendisch VF: Characterization of a Corynebacterium glutamicum lactate utilization operon induced during temperature-triggered glutamate production. Appl Environ Microbiol 2005, 71:5920-5928.

42. Haima P, van Sinderen D, Bron S, Venema G: An improved betagalactosidase alpha-complementation system for molecular cloning in Bacillus subtilis. Gene 1990, 93:41-47.

43. Brautaset $T$, Jakobsen OM, Degnes KF, Netzer R, Naerdal I, Krog A, Dillingham R, Flickinger MC, Ellingsen TE: Bacillus methanolicus pyruvate carboxylase and homoserine dehydrogenase I and II and their roles for L-lysine production from methanol at $50^{\circ} \mathrm{C}$. Appl Microbiol Biotechnol 2010, 87:951-964.

44. Say RF, Fuchs G: Fructose 1,6-bisphosphate aldolase/phosphatase may be an ancestral gluconeogenic enzyme. Nature 2010, 464:1077-1081.

45. Alexander-Kaufman K, Harper C: Transketolase: observations in alcohol-related brain damage research. Int J Biochem Cell Biol 2009, 41:717-720.

46. Kochetov G, Sevostyanova IA: Binding of the coenzyme and formation of the transketolase active center. IUBMB Life 2005, 57:491-497.

47. Bobst CE, Tabita FR: The role of cysteine 160 in thiamine diphosphate binding of the Calvin-Benson-Bassham cycle transketolase of Rhodobacter sphaeroides. Arch Biochem Biophys 2004, 426:43-54.

48. Jung EH, Takeuchi T, Nishino K, Itokawa Y: Studies on the nature of thiamine pyrophosphate binding and dependency on divalent cations of transketolase from human erythrocytes. Int J Biochem 1988, 20:1255-1259.

49. Heinrich PC, Wiss O: Transketolase from human erythrocytes Purification and properties. Helv Chim Acta 1971, 54:2658-2668.
50. Kochetov GA: Transketolase: structure and mechanism of action Biokhimiia 1986, 51:2010-2029.

51. Wikner C, Nilsson U, Meshalkina L, Udekwu C, Lindqvist Y, Schneider G: Identification of catalytically important residues in yeast transketolase. Biochemistry 1997, 36:15643-15649.

52. Schaaff-Gerstenschlager I, Mannhaupt G, Vetter I, Zimmermann FK Feldmann H: TKL2, a second transketolase gene of Saccharomyces cerevisiae Cloning, sequence and deletion analysis of the gene. Eur J Biochem 1993, 217:487-492.

53. Schaaff-Gerstenschlager I, Zimmermann FK: Pentose-phosphate pathway in Saccharomyces cerevisiae: analysis of deletion mutants for transketolase, transaldolase, and glucose 6-phosphate dehydrogenase. Curr Genet 1993, 24:373-376.

54. Domain F, Bina XR, Levy SB: Transketolase A, an enzyme in central metabolism, derepresses the marRAB multiple antibiotic resistance operon of Escherichia coli by interaction with MarR. Mol Microbiol 2007, 66:383-394.

55. Usmanov RA, Kochetov GA: Function of the arginine residue in the active center of baker's yeast transketolase. Biokhimiia 1983, 48:772-781.

56. Usmanov RA, Kochetov GA: Interaction of baker's yeast transketolase modified by 2,3-butanedione with anionic and nonanionic substrates. Biochem Int 1983, 6:673-683.

57. Bystrykh LV, de Koning W, Harder W: Dihydroxyacetone synthase from Candida boidinii KD1. Methods Enzymol 1990, 188:435-445.

58. Esakova OA, Meshalkina LE, Golbik R, Hubner G, Kochetov GA: Donor substrate regulation of transketolase. Eur J Biochem 2004, 271:4189-4194.

59. Hanahan D: Techniques for transformation of $E$ coli. In DNA cloning: a practical approach. Edited by Glover DM. Oxford, United Kingdom: IRL Press; 1985:109-135.

60. Sambrook J, Russell D: Molecular Cloning A Laboratory Manual. 3rd edition. Cold Spring Harbor, NY: Cold Spring Harbor Laboratoy Press; 2001.

61. Studier FW, Rosenberg AH, Dunn JJ, Dubendorff JW: Use of T7 RNA polymerase to direct expression of cloned genes. Methods Enzymol 1990, 185:60-89.

62. Lindner SN, Vidaurre D, Willbold S, Schoberth SM, Wendisch VF: NCgI2620 encodes a class II polyphosphate kinase in Corynebacterium glutamicum. Appl Environ Microbiol 2007, 73:5026-5033.

63. Laemmli UK: Cleavage of structural proteins during assembly of head of bacteriophage-T4. Nature 1970, 227:680.

64. Thompson JD, Higgins DG, Gibson TJ: CLUSTAL W: improving the sensitivity of progressive multiple sequence alignment through sequence weighting, position-specific gap penalties and weight matrix choice. Nucleic Acids Res 1994, 22:4673-4680.

doi:10.1186/1471-2180-14-7

Cite this article as: Markert et al:: Characterization of two transketolases encoded on the chromosome and the plasmid pBM19 of the facultative ribulose monophosphate cycle methylotroph Bacillus methanolicus. BMC Microbiology 2014 14:7

\section{Submit your next manuscript to BioMed Central and take full advantage of:}

- Convenient online submission

- Thorough peer review

- No space constraints or color figure charges

- Immediate publication on acceptance

- Inclusion in PubMed, CAS, Scopus and Google Scholar

- Research which is freely available for redistribution 